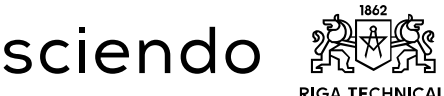 RIGA TECHNICAL
UNIVERSITY
}

\section{EXAMINING DIFFERENT FACTORS OF INCOME TAX NON-COMPLIANCE IN A SMALL SAMPLE IN BANGLADESH}

\author{
Ashir-In-TISHAR ${ }^{1}$, Syed HASANUZZAMAN ${ }^{2}$ \\ ${ }^{1}$ Unnayan Shamannay, Dhaka, Bangladesh \\ ${ }^{2}$ Shahjalal University of Science \& Technology, Sylhet, Bangladesh \\ Corresponding author's email: ashirint013@gmail.com
}

\begin{abstract}
Income tax non-compliance is worldwide delinquent and with the small volume of income tax collection Bangladesh has been facing its demerits for a long time. There is still a gap to measure income tax non-compliance behaviour in a micro direct approach. This study uses EVSCALE instrument to calculate the individual income tax non-compliance as a latent variable. The instrument consists of 15 items in Likert scale to measure the non-compliance behaviour of a person. The objective of this study is to identify the determinants of income tax non-compliance and key factors of EVSCALE in Bangladesh. The study collected opinions of taxpayers by primary data collection following a convenient sampling method. Logit regression analysis finds out that log monthly income, tax morale, tax education and occupation significantly influence income tax non-compliance. Exploratory factor analysis identifies six key factors that have consistency and shared variance. However, Cronbach's alpha shows that five key factors have high reliability among six factors. According to rules of thumb, this study suggests that EVSCALE instrument needs modification by adding more items. This study argues that increasing participation in taxation system is a feasible policy for government instead of increasing tax rate.
\end{abstract}

Keywords: Income Tax Non-Compliance, Tax Morale, Tax Education, EVSCALE, Exploratory Factor Analysis, Bangladesh.

JEL Classification: H260, C910

\section{INTRODUCTION}

According to the tax lost ranking, Bangladesh ranked 65 in the world and 18 in Asia (Murphy, 2011). National Board of Revenue (NBR, 2018) reported that the targeted income tax and travel tax was BDT (Bangladeshi Taka) 251.94 billion and the NBR collected BDT 206.4596 billion. Gap between targeted and collected income tax revenue was BDT 45.4804 billion up to November 2017. The amount of income tax collection is small in Bangladesh. Therefore, income tax noncompliance is a major concern for the country and empirical works of Hasan, Mohammad and Alam (2017), Sarkar et al. (2015) and Hasan (2014) found evidence of tax non-compliance in Bangladesh. A general hypothesis is that the morality of the people of the country is not up to the mark; however, we reject the hypothesis as Torgler (2004) found that, despite of having good tax moral, the size 
of the shadow economy of Bangladesh is very high. Morality cannot drive the people to tax compliance. There must be factors other than tax morale that influence tax non-compliance of the people. There is a long run cointegrated relationship between budget deficit and public debt in Bangladesh (Saima \& Uddin, 2017). If this deficit persists for long, the economy of the country will face constraint in the development path (Sarkar et al., 2015). To reduce the deficit, government can either increase the income tax rate or increase the participation to submit tax return. However, what will be the focus of the policy is ambiguous. Therefore, it is important to identify the influential factors of income tax non-compliance. Study identified the determinants of income tax non-compliance in Bangladesh, however, not in micro direct approach. For example, Hassan (2011) measured the unreported income calculating the 'shadow economy' and identified its key factors. The criticism of this measurement is that it has limitation to postulate the direct perception of the taxpayers. Direct survey data to measure taxpayers' compliance is more preferable according to researchers (Clotfelter, 1983; Khlif \& Achek, 2015). This study focuses on income tax non-compliance and measures it through a micro direct approach using an instrument known as EVSCALE that contains 15 items (Kasipillai \& Jabbar, 2006). Researchers (Kasipillai \& Jabbar, 2006; AlMamun et al., 2014) used this instrument in the context of Malaysia to measure the direct perception of the taxpayers. The key factors of EVSCALE are unrevealed as this study has found no exploratory or confirmatory factor analysis of EVSCALE so far. There is a gap to identify the key factors of EVSCALE to see the shared variance among the 15 items.

The objective of the study is to identify the determinants of income tax noncompliance calculating the latent variable from EVSCALE and key factors of EVSCALE instrument that has consistency and shared variance in the context of Bangladesh.

\section{LITERATURE REVIEW}

\subsection{Non-compliance}

Considering the individual perception, Jackson and Milliron (1986) estimated 14 significant determinants of tax evasion. On the contrary, Riahi-Belkaoui (2004) conducted a cross-country analysis regarding tax non-compliance without concerning the individual level. Richardson (2006) combined the cross-country framework of Riahi-Belkaoiu (2004) and the determinants postulated by Jackson and Milliron (1986) of individual level to elaborate the tax evasion concept. However, the subject matter of income tax non-compliance is vast, as IRS (Inland Revenue Services) of the USA identified 64 factors related to non-compliance behaviour (Young, 1994). People consider tax evasion as a lower level of crime compared to other criminal activities (Burton, Karlinsky \& Blanthorne, 2005), which complicate the scenario of income tax non-compliance behaviour. Therefore, Kasipillai and Jabbar (2006) state that tax compliance depends on social attitude and behavioural aspects of taxpayers; sometimes complex combination of circumstances might work as catalyst as well. 
Different researchers defined non-compliance in different ways, which resulted in controversy among the definitions. McBarnet (2001) defined non-compliance as failure to submit return, whether willingly or unwillingly. On the contrary, James and Alley (2002) emphasised imposing constraint on the continuality and narrowness of the definition. Instead of stating tax non-compliance as the failure of paying tax, they stated as the failure of tax obligation where some behaviour violated law and other did not. As tax morale varies according to culture, different countries have a different level of tax compliance (Alm \& Torgler, 2006). For example, tax compliance was higher in Singapore, New Zealand, Australia and lower in Italy, Sweden, Turkey (Riahi-Belkaoiu, 2004), while Malaysian taxpayers were moderately tax compliant (Kasipillai \& Jabbar, 2006).

\subsection{EVSCALE}

Researchers (i.e., Riahi-Belkaoui, 2004; Richardson, 2006) identified several aspects of income tax non-compliance and measured non-compliance attitude in country basis data with proxy variable that barely considered individual's opinion (Khlif \& Achek, 2015). Roberts (1994) constructed a measurement instrument, named after Noncomp, to measure tax non-compliance and made an experimental analysis among students. The reliability test showed high reliability of the instrument with 0.93 value of Cronbach's alpha. The measurement instrument consisted of 15 items with a seven-point Likert scale starting from 1 (very noncompliance behaviour) to 7 (very compliance behaviour). Later, Kasipillai and Jabbar (2006) used 13 items from Noncomp and added two items in the context of Malaysia. They named the measurement instrument after EVSCALE. Kasipillai and Jabbar (2006) used EVSCALE to measure the individual non-compliance attitude in a micro direct approach. Al-Mamun et al. (2014) measured the non-compliance behaviour in Malaysia using this instrument as well. The instrument has been experimented in developing Asian economy like Malaysia, however, not in the context of Bangladesh.

\subsection{Income Level and Income Tax Non-compliance}

Pissarides and Weber (1989) found that British people had actually 1.55 times higher income than they reported. This deliberate under reporting of income creates ambiguity to shape the income tax non-compliance behaviour. Evidence shows that higher income people have a good record in the case of tax compliance comparing to lower income people (Muibi \& Sinbo, 2013). Kong and Wang (2014) experimented that high- and low-class earners were more tax non-compliant compared to middle-class earners. On the other hand, Witte and Woodbury (1985) found that middle income earners were more compliant. Although the income level impacts non-compliance behaviour of the people, the extent of influence is equivocal.

\subsection{Age and Income Tax Non-compliance}

Age significantly influences the non-compliance behaviour of the people. Clotfelter (1983) investigated that younger taxpayers are more non-compliant than 
older taxpayers. This result was stable in 33 different countries (McGee \& Tayler, 2006) and in Australia (Wenzel, 2004). Older people have more social attachments that make them more compliant (Torgler, 2004). On the contrary, the finding of Wahlund (1992) is equivocal as he found otherwise in Sweden. Palil (2010) opined that young people had more ethical obligation compared to elders and thus they had more compliance. However, Richardson (2006) found no significant relationship between tax non-compliance and age. Due to different socio-economic and demographic behaviour, the role of age differs in the case of constructing noncompliance.

\subsection{Role of Tax Knowledge and Tax Morale on Income Tax Non-compliance}

Empirical studies found that the more a person had tax knowledge, the more income tax compliance the person possessed (Kirchler \& Maciejovsky, 2001; Obid, 2004; Roshidi, Mustafa \& Asri, 2007). Study found that possessing different tax knowledge, male made their own decision of attitude towards compliance while female reconsidered other's attitude towards compliance behaviour (Fallan, 1999). On the contrary, tax knowledge has detrimental impact as vast knowledge of taxation sometimes leads to very low tax compliance by finding loop holes for tax evasion (Groenland \& van Veldhoven, 1983). Tax morale not only indicates individual's behaviour, but also illustrates individual's attitude (Torgler, 2003). Moral obligation plays a significant role in terms of non-compliance behaviour (Bobek \& Hatfield, 2003). Asian countries have goodwill about having a good tax morality (e.g., Japan, China, India and Bangladesh); however, non-compliance behaviour is still a major concern (Torgler, 2004). However, people are more noncompliant when they possess ambivalent tax morale (Witte \& Woodbury, 1985).

\subsection{Occupational Obligation and Income Tax Non-compliance}

Occupational variety influences the non-compliance behaviour of the people (Andreoni, Erard \& Feinstein, 1998). In Albania and Netherlands, people consider the probability of evasion while deciding on the source of income (Gërxhani \& Schram, 2006). Usually, people engaged in agriculture with small trade volume, small business and private enterprise have more opportunity to evade tax (Kong \& Wang, 2014). In the United Kingdom, self-employed people were more income tax non-compliant and they understated their income complaining that they had to spend more on food. However, we can reject this opinion as there was no evidence regarding higher propensity to food consumption at that time in England (Pissarides \& Weber, 1989).

\section{METHODOLOGY}

The area of the study is Sylhet City Corporation; a divisional city of Bangladesh. Sylhet is renowned for remittance and vast economic activities in the northeast part of the country. Bangladesh follows a similar income tax law all over the country. Therefore, a taxation pattern of Sylhet is not different from other parts of the country. 
The study collected primary data from the respondents having taxable income through a direct interview method by means of semi-structured questionnaire. The questionnaire consists of information about respondents' demographic and income status (Riahi-Belkaoui, 2004; Richardson, 2006). Information regarding income tax non-compliance has been collected using EVSCALE (Kasipillai \& Jabbar, 2006), with a five-point Likert scale. The income tax law of the government of Bangladesh exempts people having yearly income less than BDT 250,000 (about USD 2900). There are also additional exemptions for women, elderly and agro-based earnings (Bangladesh Gadget, 2015). These facilities ensure that people having taxable earning are not from the extreme poor or the vulnerable groups. Thus, we can assume that people who are tax evaders willingly do it. We can easily assume that tax evaders know about the illegal nature of their act. They have motivated us to develop an incentive model related to illegal activities.

Because of the illegal nature of the data, this study has followed a convenience sampling method. This sampling method has also been conducted in the context of Malaysia (Ser, 2013), the USA and Hong Kong (Chan, Troutman \& O'Bryan, 2000). Convenience sampling method has the advantage over reliability, time and budget constraint. Questionnaires were delivered to people of various income level, education level and professional diversity between October and November, 2016.

\subsection{Methods of Data Analysis}

\subsubsection{Logit Regression}

The dependent variable income tax non-compliance is binary calculated from cross-sectional data. Therefore, the study uses a logit regression model to identify the determinants of income tax non-compliance as follows:

$$
\operatorname{logit}(\pi)=\frac{\pi}{1-\pi}=\alpha+\beta^{\prime} X
$$

where,

$\pi$ is the probability of a person of being income tax non-compliant or not;

$\alpha$ is the intercept term;

$\beta$ is the vector of co-efficient parameter; and

$X$ is the vector of explanatory variables.

In addition, the study calculates the odds ratio to identify the likelihood of impact of an explanatory variable on the explained variable.

\subsubsection{Exploratory Factor Analysis}

This study identifies the latent key factors from EVSCALE calculating the eigenvalues from the exploratory factor analysis using rotated varimax. Although a principal component analysis (PCA) is a popular method to find the key factors, it does not differentiate between shared variance and unique variance (Costello \& Osborne, 2005). On the contrary, researchers (i.e., Bentler \& Kano, 1990; Floyd \& Widaman, 1995) prefer the factor analysis to the principal component analysis as the factor analysis identifies the latent variables that consider the shared variance rejecting the uncorrelated variance that yields better latent variables with integrity. 


\section{Kaiser-Meyer-Olkin Test and Bartlett's Test of Sphericity}

The Kaiser-Meyer-Olkin (KMO) test result of this study is 0.615 . The sample size is adequate for the factor analysis as the value is greater than the required value 0.50 (Kaiser, 1970; Kaiser, 1974; Hair et al., 1995; Costello \& Osborne, 2005). The Bartlett's Test of Sphericity is significant $(p=0.00)$ at $1 \%$ confidence interval which is better than the required less than $95 \%(p<0.05)$ confidence interval (Hair, 1995; Costello \& Osborne, 2005), indicating that the factor analysis is suitable with the available data.

\subsection{Variables of the Study in Logit Regression}

\section{Independent Variable}

The independent variables of the study are log monthly income (continuous), age (continuous), tax education (binary), tax morale (binary) and occupation (binary) (Table 1).

Table 1. The independent variables of the study

\begin{tabular}{|l|l|l|}
\hline \multicolumn{1}{|c|}{ Name } & \multicolumn{1}{c|}{ Type } & \multicolumn{1}{c|}{ Description } \\
\hline $\begin{array}{l}\text { Log monthly } \\
\text { income }\end{array}$ & Continuous & $\begin{array}{l}\text { Monthly log income of the respondent in per thousand BDT in } \\
\text { log form. }\end{array}$ \\
\hline Age & Continuous & Age of the respondent in terms of year. \\
\hline Tax education & Binary Dummy & 1 if respondent has tax education and 0 otherwise. \\
\hline Tax morale & Binary Dummy & 1 if respondent has morale obligation on tax and 0 otherwise. \\
\hline Occupation & Binary Dummy & $\begin{array}{l}1 \text { if there is any occupational regulation to submit tax, e.g., } \\
\text { automatic tax adjusted salary, trade license etc. and 0 otherwise. }\end{array}$ \\
\hline
\end{tabular}

\section{Dependent Variable}

The dependent variable is involvement in illegal activity: income tax noncompliance. This is a latent variable calculated from EVSCALE. The variable considers income tax non-compliance as 1 and income tax not non-compliance as 0 . However, as we have restricted our sample among persons with tax payable income, a respondent can either be income tax compliant or not. The threshold of calculating non-compliance is three (neutrality) of five-point Likert scale. Respondent is non-compliant, if he or she remains equal or above this threshold. Each individual answered all these 15 items with slight reforms in the context of Bangladesh. Income tax non-compliance is a latent variable here with the following calculation:

Income tax non - compliant $=1 ;$ if,$\frac{\text { Sum of the scores of likert scale }}{\text { Total number of questions }} \geq 3$ and

$$
\text { = } 0 \text {; otherwise }
$$




\section{RESULTS}

In total, 112 respondents filled in the questionnaire completely. Younger respondents were more enthusiastic to participate as most of the respondents $(45.54 \%)$ were aged between 31 to 45 , followed by 23 to $30(31.25 \%), 41-50$ $(13.39 \%)$ and $51-60(8.93 \%)$. Among the respondents, $55.36 \%$ completed postgraduate studies and $16.96 \%$ completed graduation, while $8.04 \%$ had no schooling year. Around $72.32 \%$ of the total respondents had monthly income in between BDT 24,000 to BDT 70,000 followed by $16.96 \%$ of respondents whose income was in between BDT 70,000 to BDT 120,000.

According to equation (2), the study finds that 34 respondents are income tax non-compliant and 78 are income tax compliant. The ratio of income tax compliant respondents $(69.64 \%)$ is higher than that of income tax non-compliant respondents $(30.36 \%)$. The overall average score of EVSCALE is 2.602976 with standard deviation 0.579693 (Table 2). Most of the respondents revealed their noncompliance behaviour in the case of a higher tax rate (item 6), lack of trust in government activities (item 11), high living cost (item 13), bartering goods (item 14) and uncertainty about taxable income (item 15). It will not be a feasible policy for the government to increase the existing rate of tax to recover deficit budget.

Table 2. Mean of EVSCALE

\begin{tabular}{|l|l|c|}
\hline & \multicolumn{1}{|c|}{ Non-compliance attitude [EVSCALE items] } & Mean \\
\hline 1 & If one is paid in cash for a job and then does not report in the tax return & 2.5 \\
\hline 2 & $\begin{array}{l}\text { Under a self-assessment system, it is not wrong to omit or understate taxable } \\
\text { income }\end{array}$ & 2.258929 \\
\hline 3 & $\begin{array}{l}\text { It is worthwhile understating a little of taxable income as the audit } \\
\text { probability is very low }\end{array}$ & 2.991071 \\
\hline 4 & $\begin{array}{l}\text { Being a law-abiding individual, it is alright to occasionally understate certain } \\
\text { income or claim a disallowable expense }\end{array}$ & 1.955357 \\
\hline 5 & $\begin{array}{l}\text { Failing to declare some earnings from investment of commissions whose } \\
\text { authority will not found it ethical }\end{array}$ & 1.785714 \\
\hline 6 & $\begin{array}{l}\text { It is ok to bend existing rules, to pay less is not cheating when income tax } \\
\text { rates are too high }\end{array}$ & 3.178571 \\
\hline 7 & $\begin{array}{l}\text { You know you deserve a deduction that you are not entitled for, it is not } \\
\text { wrong to replace it with some other deduction which the authority will not } \\
\text { be able to find out }\end{array}$ & 2.732143 \\
\hline 8 & Declare your principal fully, but avoid part-time income & 1.8125 \\
\hline 9 & $\begin{array}{l}\text { It is not wrong to understate some income as it does not really hurt anyone } \\
\text { directly }\end{array}$ & 2.026786 \\
\hline 10 & $\begin{array}{l}\text { It is alright not to declare and pay any more income tax, as income tax is } \\
\text { deducted monthly by the employer }\end{array}$ & 2.919643 \\
\hline 11 & $\begin{array}{l}\text { It is not too wrong to declare less on taxable income as government spends } \\
\text { too much on extravagant projects }\end{array}$ & 3.125 \\
\hline 12 & $\begin{array}{l}\text { Several businessman do not pay income taxes; hence, it is not a big deal if } \\
\text { someone like you understate a little }\end{array}$ & 2 \\
\hline & \multicolumn{1}{|c|}{ ingen } \\
\hline
\end{tabular}




\begin{tabular}{|c|l|c|}
\hline & \multicolumn{1}{|c|}{ Non-compliance attitude [EVSCALE items] } & Mean \\
\hline 13 & $\begin{array}{l}\text { With high living cost these days, it is okay to claim more expenses to help } \\
\text { make ends meet }\end{array}$ & 3.098214 \\
\hline 14 & $\begin{array}{l}\text { When you barter goods with a friend, it is not wrong not to report on your } \\
\text { tax return }\end{array}$ & 3.508929 \\
\hline 15 & $\begin{array}{l}\text { When you are not really sure whether or not an expense is allowable, it } \\
\text { makes sense to claim the deduction anyway }\end{array}$ & 3.151786 \\
\hline & Overall & 2.602976 \\
\hline
\end{tabular}

\subsection{Determinants of Income Tax-Non-compliance}

The logit regression analysis shows that log monthly income, tax education, tax morale and occupation significantly (at $1 \%$ statistical significant level of significance) influence income tax non-compliance behaviour (Table 3 ). The model converges after 5 iterations with pseudo $R^{2}$ value 0.8786 , indicating satisfactory predictability of the model.

According to the findings, higher income respondents are less likely income tax non-compliant. The odds of income tax non-compliance of affluent respondents are $89.6 \%$ less than that of the relatively low-class earners. Similar result was found in the empirical work by many researchers in different countries (Richardson, 2006, McGee \& Tayler, 2006; Muibi \& Sinbo, 2013).

Tax educated people are less likely to be income tax non-compliant comparing to people who have no tax education. The likelihood of income tax non-compliance of the persons having tax education is $92.05 \%$ less than that of the persons having no tax education (Table 3 ).

Table 3. Income Tax Non-compliance Determinants

\begin{tabular}{|l|c|c|c|}
\hline \multicolumn{1}{|c|}{ Name of the variables } & Logit coefficient & Standard error & Odds ratio \\
\hline Log monthly income & $-2.267 * * *$ & 0.769 & $0.1035992 * * *$ \\
\hline Age & 0.102 & 0.220 & 1.10746 \\
\hline Age2 & -0.000990 & 0.00243 & 0.9990103 \\
\hline Tax education & $-2.532 * * *$ & 0.921 & $0.0794633 * * *$ \\
\hline Tax morale & $-2.461 * * *$ & 0.688 & $0.0853473 * * *$ \\
\hline Occupation & $-1.580^{* * *}$ & 0.599 & $0.2060428 * * *$ \\
\hline Constant & $21.78^{* * *}$ & 7.683 & \\
\hline Observations & 112 & & \\
\hline
\end{tabular}

Notes: Pseudo $R$-squared $=0.8786$; Robust standard errors; Level of significance $=* * * p<0.01$, $* * p<0.05, * p<0.1$

The result supports the findings of Kirchler and Maciejovsky, (2001), Obid (2004) and Roshidi et al. (2007). When persons do not have tax education or knowledge, they have to consult with lawyer or tax officials to prepare tax return. This requires extra cost and time that make people demure to submit tax return. Clotfelter (1983) stated that complexity of the tax system leads to this type of 
problem and the phenomenon is similar to the empirical findings in Austria (Kirchler \& Maciejovsky, 2001), Japan (Sarker, 2003) and Malaysia (Ser, 2013).

The estimated odds ratio significantly illustrates that the probability of respondents being income tax non-compliant having good tax morale is $91.47 \%$ less than that of the respondents having no tax morale (Table 3). Like other studies (e.g., Bobek \& Hatfield, 2003; Ser, 2013), this study finds that higher morality is related to lower income tax non-compliance. However, this study cannot find out what actually drives the morality attitude into compliant action.

Respondents having occupational regulation to pay taxes are less likely income tax non-compliant than that of respondents having no occupational regulation to pay taxes. The likelihood of income tax non-compliance of the respondents having occupational regulation to pay taxes is $79.4 \%$ less than that of the respondents having no occupational regulation to pay taxes. This result indicates that income tax authority has little or no monitoring on the income of businessmen, small businessmen and some other private job holders who self-submit their return. Therefore, they have scope to understate their income, which is a weakness of the existing self-assessment system.

\subsection{Factors of EVSCALE}

The study will not consider the factors significant that have eigenvalues less than 1 (Kaiser, 1960; Fabrigar et al., 1999). According to the analysis, six factors have eigenvalues greater than 1 and explain the most variance $(75.88 \%$ of the total variance) in terms of 15 items (Table 4).

Table 4. Factors and Eigenvalues

\begin{tabular}{|c|c|c|c|c|}
\hline Factor & Eigenvalue & Difference & Proportion & Cumulative \\
\hline Factor1 & $\mathbf{3 . 8 8 9 0 5}$ & 2.05750 & 0.2593 & $\mathbf{0 . 2 5 9 3}$ \\
\hline Factor2 & $\mathbf{1 . 8 3 1 5 5}$ & 0.12527 & 0.1221 & $\mathbf{0 . 3 8 1 4}$ \\
\hline Factor3 & $\mathbf{1 . 7 0 6 2 8}$ & 0.27099 & 0.1138 & $\mathbf{0 . 4 9 5 1}$ \\
\hline Factor4 & $\mathbf{1 . 4 3 5 3 0}$ & 0.02586 & 0.0957 & $\mathbf{0 . 5 9 0 8}$ \\
\hline Factor5 & $\mathbf{1 . 4 0 9 4 4}$ & 0.29969 & 0.0940 & $\mathbf{0 . 6 8 4 8}$ \\
\hline Factor6 & $\mathbf{1 . 1 0 9 7 4}$ & 0.25037 & 0.0740 & $\mathbf{0 . 7 5 8 8}$ \\
\hline Factor7 & 0.85937 & 0.11956 & 0.0573 & 0.8160 \\
\hline Factor8 & 0.73981 & 0.07774 & 0.0493 & 0.8654 \\
\hline Factor9 & 0.66207 & 0.04591 & 0.0441 & 0.9095 \\
\hline Factor10 & 0.61615 & 0.3349 & 0.0411 & 0.9506 \\
\hline Factor11 & 0.28266 & 0.13244 & 0.0188 & 0.9694 \\
\hline Factor12 & 0.15022 & 0.02981 & 0.0100 & 0.9794 \\
\hline Factor13 & 0.12041 & 0.00906 & 0.0080 & 0.9875 \\
\hline Factor14 & 0.11135 & 0.03475 & 0.0074 & 0.9949 \\
\hline Factor15 & 0.07661 & & 0.0051 & 1.0000 \\
\hline
\end{tabular}


The study then used varimax rotation to make the factors more interpretable and found that the uniqueness to the variability of the data matrix was highest in q6 and lowest in q14 (Table 5). While q6 had the most unique variance (lowest communalities), q14 had most shared variance (highest communalities). The threshold value for factor loading cut off is 0.40 (Stevens, 2002; Lancaster et al., 2017). Result shows that Factor1 consists of two items (q3, q7). Factor 2 consists of three items (q2, q4, q6), Factor3 consists of three items (q10, q11, q13), Factor4 consists of two items (q8, q5), Factor5 of consists two items (q14, q15) and Factor6 consists of three items (q12, q9, q1).

Table 5. Factors and Uniqueness

\begin{tabular}{|c|c|c|c|c|c|c|c|}
\hline Variable & Factor1 & Factor2 & Factor3 & Factor4 & Factor5 & Factor6 & Uniqueness \\
\hline q3 & $\mathbf{0 . 9 2 6 6}$ & 0.1362 & 0.0971 & 0.0841 & 0.0741 & 0.0448 & $\mathbf{0 . 0 9 8 9}$ \\
\hline q7 & $\mathbf{0 . 8 9 6 0}$ & 0.1469 & 0.1381 & 0.0567 & 0.1842 & 0.0505 & $\mathbf{0 . 1 1 6 9}$ \\
\hline q 2 & 0.1746 & $\mathbf{0 . 9 0 6 3}$ & 0.0628 & 0.0405 & 0.1156 & 0.0177 & $\mathbf{0 . 1 2 8 9}$ \\
\hline q4 & 0.1473 & $\mathbf{0 . 8 9 5 0}$ & 0.0473 & 0.1361 & 0.1583 & 0.0528 & $\mathbf{0 . 1 2 8 7}$ \\
\hline q6 & 0.2727 & $\mathbf{0 . 4 1 1 5}$ & 0.1671 & 0.1958 & 0.1807 & 0.1953 & $\mathbf{0 . 6 1 9 2}$ \\
\hline q10 & 0.1383 & 0.0112 & $\mathbf{0 . 8 6 0 1}$ & 0.0318 & 0.0948 & 0.1733 & $\mathbf{0 . 2 0 1 0}$ \\
\hline q11 & 0.1686 & 0.0472 & $\mathbf{0 . 8 4 3 2}$ & 0.0907 & 0.1533 & 0.0059 & $\mathbf{0 . 2 2 6 6}$ \\
\hline q13 & 0.0406 & 0.3714 & $\mathbf{0 . 6 1 0 7}$ & 0.0626 & 0.0090 & 0.2234 & $\mathbf{0 . 4 3 3 5}$ \\
\hline q8 & 0.0809 & 0.0072 & 0.0373 & $\mathbf{0 . 9 3 9 5}$ & 0.0773 & 0.1150 & $\mathbf{0 . 0 9 0 2}$ \\
\hline q5 & 0.0661 & 0.1382 & 0.0235 & $\mathbf{0 . 9 2 8 5}$ & 0.1412 & 0.0192 & $\mathbf{0 . 0 9 3 5}$ \\
\hline q14 & 0.1083 & 0.0882 & 0.0995 & 0.1454 & $\mathbf{0 . 9 2 5 8}$ & 0.0139 & $\mathbf{0 . 0 9 2 2}$ \\
\hline q15 & 0.1252 & 0.1465 & 0.0892 & 0.0717 & $\mathbf{0 . 9 1 6 9}$ & 0.0270 & $\mathbf{0 . 1 0 8 4}$ \\
\hline q12 & 0.2124 & 0.0708 & 0.0276 & 0.2846 & 0.1166 & $\mathbf{0 . 6 6 2 6}$ & $\mathbf{0 . 4 1 5 5}$ \\
\hline q9 & 0.1032 & 0.1248 & 0.3441 & 0.1231 & 0.1051 & $\mathbf{0 . 6 1 6 9}$ & $\mathbf{0 . 4 4 8 6}$ \\
\hline q1 & 0.4552 & 0.1028 & 0.1022 & 0.2878 & 0.0219 & $\mathbf{0 . 5 2 1 5}$ & $\mathbf{0 . 4 1 6 4}$ \\
\hline
\end{tabular}

However, the factors are not reliable if the Cronbach's alpha value is below 0.6 (Murphy and Davidshoter, 1988). The overall Cronbach's alpha value of EVSCALE is 0.78 (greater than 0.6) that is reliable and acceptable (Table 6).

Table 6. Reliability Test of Cronbach's Alpha

\begin{tabular}{|c|c|}
\hline Item & Cronbach's alpha \\
\hline Overall & 0.78 \\
\hline Factor1 & 0.9524 \\
\hline Factor2 & 0.6444 \\
\hline Factor3 & 0.7171 \\
\hline Factor4 & 0.9246 \\
\hline Factor5 & 0.9069 \\
\hline Factor6 & 0.2096 \\
\hline
\end{tabular}


Analysis shows that all the factors are reliable with high reliability except the last one. According to the rules of thumb, more items are required to get high reliability for successful explanation of this factor.

\section{DISCUSSION}

This study has analysed that people having tax education are less likely to be income tax non-compliant; however, the phenomenon is not same in all the areas. Other studies (i.e., Groenland \& van Veldhoven, 1983;) had opposite result illustrating that people used their knowledge to evade or avoid tax. Therefore, it is important to improve morale obligation to ensure how a person uses the acquired tax knowledge.

Kasipillai (2005) stated that countries that followed the self-assessment system were more tax compliant, and the self-assessment system upgraded compliance obligation among the taxpayers (Sapiei \& Kasipillai, 2013). In Australia, tax return submission increased remarkably after introducing the self-assessment system (Marshall, Smith \& Armstrong, 1997). However, our study has demonstrated the opposite result. We have observed that those who self-submit tax return and have no occupational regulation to pay taxes are more likely non-compliant.

Self-assessment system cannot preclude income tax non-compliance behaviour in the case of Bangladesh. Occupations having tax regulation have more audit probability and maybe this is the reason for the respondents to be compliant (Andreoni et al., 1998). Therefore, it is also equally important to improve the morale obligation to pay income tax under the self-assessment system.

So far, the study has observed that without morality, it is difficult for a person to be income tax compliant even though having tax education under the selfassessment system. While affluent respondents are more likely compliant, it is uncertain whether they are more compliant due to frequent surveillance or not. However, morale obligation cannot drive people to compliance when they have a lower income level.

As mentioned earlier, Torgler (2004) stated that, despite of having good tax morale, people of Bangladesh were less tax compliant and he did not find any reason behind this. From the present study, we can say that Bangladesh has a lower level of compliance despite having good tax morale due to being a lower per capita income country. The successful self-assessment system countries have more per capita income than Bangladesh. For instance, in 2016, Malaysia and Australia had USD 11,028.20 and USD 55,670.9 per capita income, respectively. Both countries enjoy the fruitfulness of the self-assessment system (Sapiei \& Kasipillai, 2013; Marshall et al., 1997).

On the contrary, the potentials of self-assessment system is parochial in Bangladesh with USD 1602 per capita income in 2017. There is a huge difference between per capita income of Bangladesh and Malaysia, especially between Bangladesh and Australia. 


\section{CONCLUSION}

The study has used EVSCALE instrument to estimate income tax noncompliance behaviour in two ways. The exploratory factor analysis has found six key factors of EVSCALE and Cronbach's alpha value has ensured that the factors are reliable except one. Therefore, according to the rules of thumb, the study suggests that the measurement scale requires more items to explain the key factors reliably. The study has also used EVSCALE to calculate income tax noncompliance as a latent variable, then identified key determinants using a logit regression model. Analysis has found that log monthly income, tax education, tax morale and occupation significantly influence the income tax non-compliance, while age has no significant influence. Besides, respondents have revealed their non-compliance behaviour regarding the existing tax rate of the country. Increasing the tax rate may hamper the income tax revenue according to the Laffer Curve assumption. In contrast, Bangladesh has opportunity to engage more people in the taxation system. To reduce the deficit budget, it is better to elucidate the tax policy so that people find it easy to participate. The study had time and budget constraint that restricted the sample size.

\section{REFERENCES}

Alm, J., \& Torgler, B. (2006). Culture Differences and Tax Morale in the United States and in Europe. Journal of Economic Psychology, 27(2), 224-246. https://doi.org/10.1016/j.joep.2005.09.002

Al-Mamun, A., Entebang, H., Mansor, S. A., Yasser, Q. R., Nathan, T. M., \& Rahman, M. A. (2014). The Impact of Demographic Factors on Tax Compliance Attitude and Behavior in Malaysia. Journal of Finance, Accounting and Management, 5(1), 109-124. Retrieved from https://pdfs.semanticscholar.org/675e/b518b4d13c0d8352367999a568c4fc797735.pdf

Andreoni, J., Erard, B., \& Feinstein, J. (1998). Tax compliance. Journal of Economic Literature, 36(2), 818860. Retrieved from https://www.jstor.org/stable/2565123

Bangladesh Gadget. June, (2015). Retrieved $10 \quad$ January, 2017 from http://www.nbr.gov.bd/contents/act/24.pdf

Bentler, P. M. \& Kano, Y. (1990). On the Equivalence of Factors and Components. Multivariate Behavioral Research, 25(1), 67-74. https://doi.org/10.1207/s15327906mbr2501_8

Bobek, D. D., \& Hatfield, R. C. (2003). An Investigation of the Theory of Planned Behavior and the Role of Moral Obligation in Tax Compliance. Behavioral Research in Accounting, 15(1), 13-38. https://doi.org/10.2308/bria.2003.15.1.13

Burton, H. A., Karlinsky, S. S., \& Blanthorne, C. (2005). Perception of a White-Collar Crime: Tax evasion. The ATA Journal of Legal Tax Research, 3(1), 35-48. https://doi.org/10.2308/jltr.2005.3.1.35

Chan, C. W., Troutman, C. S., \& O’Bryan, D. (2000). An Expanded Model of Taxpayer Compliance: Empirical Evidence from the United States and Hong Kong. Journal of International Accounting, Auditing and Taxation, 9(2), 83-103. https://doi.org/10.1016/S1061-9518(00)00027-6

Clotfelter, C. T. (1983). Tax Evasion and Tax Rates: An Analysis of Individual Returns. The Review of Economics and Statistics, 65(3), 363-373. https://doi.org/10.2307/1924181

Costello, A.B., \& Osborne, J.W. (2005). Best Practices in Exploratory Factor Analysis: Four Recommendations for Getting the Most from your Analysis. Practical Assessment, Research \& Evaluation, 10(7), 1-9. Retrieved from https://pareonline.net/pdf/v10n7.pdf

Fabrigar, L. R., Wegener, D. T., MacCallum, R. C., \& Strahan, E. J. (1999). Evaluating the Use of Exploratory Factor Analysis in Psychological Research. Psychological Methods, 4(3), 272-299. https://doi.org/10.1037//1082-989x.4.3.272

Fallan, L. (1999). Gender, Exposure to Tax Knowledge, and Attitudes Towards Taxation; an Experimental Approach. Journal of Business Ethics, 18(2), 173-184. Retrieved from http://www.jstor.org/stable/25074044 
Floyd, F. J., \& Widaman, K. F. (1995). Factor Analysis in the Development and Refinement of Clinical Assessment Instruments. Psychological Assessment, 7(3), 286-299. https://doi.org/10.1037//1040$\underline{3590.7 .3 .286}$

Gërxhani, K., \& Schram, A. (2006). Tax Evasion and Income Source: A Comparative Experimental Study. Journal of Economic Psychology, 27(3), 402-422. https://doi.org/10.1016/j.joep.2005.08.002

Groenland, E. A. G., \& van Veldhoven, G. M. (1983). Tax Evasion Behavior: A Psychological Framework. Journal of Economic Psychology, 3(2), 129-144. https://doi.org/10.1016/0167-4870(83)90069-7

Hair, J., Anderson, R.E., Tatham, R.L. \& Black, WC. (1995). Multivariate Data Analysis. 4th ed. New Jersey: Prentice-Hall Inc.

Hasan, R. (2014). The Tendency toward Tax Evasion in Bangladesh. World Journal of Social Sciences, 3(3), 149-161. Retrieved from http://www.wjsspapers.com/static/documents/October/2014/12.\%20Rashedul.pdf

Hasan, R., Mohammad, N., \& Alam, M. F. (2017). Tax Compliance in Bangladesh - A Structural Equation Modelling Approach. American Journal of Trade and Policy, 4(1), 15-22. http://dx.doi.org/10.18034/ajtp.v4i1.980

Hassan, M. K. (2011). The shadow economy of Bangladesh: Size Estimation and Policy Implications. Transparency International Bangladesh Research Report, 1-21. Retrieved from https://www.tibangladesh.org/research/Shadow\%20Economy\%20Report\%20for\%20Web\%2011\%20Jan\%2011.pdf

Jackson, B. R., \& Milliron, V. C. (1986). Tax Compliance Research: Findings, Problems, and Prospects. Journal of Accounting Literature, 5(1), 125-165.

James, S., \& Alley, C. (2002). Tax Compliance, Self-Assessment and Tax Administration. Journal of Finance and Management in Public Service, 2(2), 27-42. Retrieved from https://ore.exeter.ac.uk/repository/bitstream/handle/10036/47458/james2.pdf?sequence=1

Kaiser, H.F. (1960). The Application of Electronic Computers to Factor Analysis. Educational and Psychological Measurement, 20, 141-151. https://doi.org/10.1177/001316446002000116

Kaiser, H.F. (1970). A Second-Generation Little Jiffy. Psychometrika, 35(4), 401-415. https://doi.org/10.1007/BF02291817

Kaiser, H.F. (1974). Little Jiffy, Mark IV. Educational and Psychological Measurement. 34, 111-117. https://doi.org/10.1177/001316447403400115

Kasipillai, J. (2005). A Comprehensive Guide to Malaysian Taxation under Self-Assessment System, 2nd ed., Selangor: McGraw Hill

Kasipillai, J., \& Jabbar, H.A. (2006). Gender and Ethnicity Differences in Tax Compliance. Asian Academy of Management Journal, 11(2), 73-88. Retrieved from http://eprints.usm.my/35944/1/AAMJ_11-2-5.pdf

Khlif, H., \& Achek, I. (2015). The Determinants of Tax Evasion: a Literature Review. International Journal of Law and Management, 57(5), 486-497. Retrieved from https://www.springer.com/cda/content/document/cda_downloaddocument/9783319324180c2.pdf?SGWID=0-0-45-1569685-p179931254

Kirchler, E., \& Maciejovsky, B. (2001). Tax Compliance within the Context of Gain and Loss Situations, Expected and Current Asset Position, and Profession. Journal of Economic Psychology, 22(2), 173-194. https://doi.org/10.1016/S0167-4870(01)00028-9

Kong, F. \& Wang, C. (2014). The Determinants of Tax Evasion : A Literature Review. Gdanskie Studia Azji Wschodniej 5, 70-78. Retrieved from http://www.ejournals.eu/pliki/art/3141/

Lancaster, S., Rodriguez, B., Lancaster, S. L., Melka, S. E., \& Rodriguez, B. F. (2017). A Factor Analytic Comparison of Five Models of PTSD Symptoms, Journal of Anxiety Disorders, 23(2), 269-274. http://doi.org/10.1016/j.janxdis.2008.08.001

Marshall, R., Smith, M., \& Armstrong, R. W. (1997). Self-Assessment and the Tax Audit Lottery: the Australian Experience. Managerial Auditing Journal, 12(1), 9-15. https://doi.org/10.1108/02686909710155957

McBarnet, D. (2001). When Compliance is not the Solution but the Problem: From Changes in Law to Changes in Attitude. Centre for Tax System Integrity (CSTI), The Australian National University. Retrieved from https://openresearch-repository.anu.edu.au/bitstream/1885/41635/2/WP18.pdf

McGee, R. W., \& Tyler, M. (2006). Tax Evasion and Ethics: a Demographic Study of 33 Countries. Researchgate Publication, 1-20. https://doi.org/10.2139/ssrn.940505

Muibi, S. O., \& Sinbo, O. O. (2013). Macroeconomic Determinants of Tax Revenue in Nigeria (1970-2011), 28(1), 27-35. https://doi.org/10.5829/idosi.wasj.2013.28.01.1189

Murphy, K. R., \& Davidshoter, C. O. (1988). Psychological Testing: Principles and Applications. Englewood Cliffs, NJ: Prentice-Hall.

Murphy, R. (2011). The Cost of Tax Abuse: A Briefing Paper on the Cost of Tax Evasion Worldwide. The Tax Justice Network, 1-20. Retrieved from https://www.taxjustice.net/wp-content/uploads/2014/04/Cost-ofTax-Abuse-TJN-2011.pdf

NBR (2018). Revenue Collection up to November, 2017, National Board of Revenue. 
Obid, S. N. S. (2004). The influence of penalties on taxpayers' compliance: A comparison of the Theoretical Models. Iium Journal of Economic and Management, 12(1), 1-31. Retrieved from http://journals.iium.edu.my/enmjournal/index.php/enmj/article/view/98/81

Palil, R. (2010). Tax Knowledge and Tax Compliance Determinants in Self-Assessment System in Malaysia. A Thesis Submitted to The University of Birmingham for the Degree of Doctor of Philosophy, Department of Accounting and Finance Birmingham Business School.

Pissarides, C. A., \& Weber, G. (1989). An Expenditure-Based Estimate of Britain's Black Economy. Journal of Public Economics, 39(1), 17-32. https://doi.org/10.1016/0047-2727(89)90052-2

Riahi-Belkaoui, A. (2004). Relationship between Tax Compliance Internationally and Selected Determinants of Tax Morale. Journal of International Accounting, Auditing and Taxation, 13(2), 135-143. https://doi.org/10.1016/j.intaccaudtax.2004.09.001

Richardson, G. (2006). Determinants of Tax Evasion: A Cross-Country Investigation. Journal of International Accounting, Auditing and Taxation, 15(2), 150-169. https://doi.org/10.1016/j.intaccaudtax.2006.08.005

Roberts, M. L (1994). An Experimental Approach to Changing Taxpayers' Attitudes towards Fairness and Compliance via Television. The Journal of the American Taxation Association, 16(1), 67-86.

Roshidi, M. A., Mustafa, H., \& Asri, M. (2007). The Effects of Knowledge on Tax Compliance Behaviors among Malaysian Taxpayers. Business and Information, 4.

Saima, U., \& Uddin, M. K. (2017). The Relationship between Budget Deficit and Public Debt in Bangladesh: A Vector Error Correction Model (VECM) Approach. Imperial Journal of Interdisciplinary Research, 3(7), 623-628. Retrieved from https://www.onlinejournal.in/IJIRV3I7/103.pdf

Sapiei, N. S., \& Kasipillai, J. (2013). Impacts of the Self-Assessment System for Corporate Taxpayers. American Journal of Economics, 3(2), 75-81. https://doi.org/10.5923/j.economics.20130302.03

Sarkar, S., Nodee, M., Musleh, M., \& Reza, S. M. S. (2015). VAT reform in Bangladesh : perspectives on Tax Morale. International Journal of Business and Management Study, 2(2), 289-293. Retrieved from https://www.researchgate.net/profile/Mahpara_Nodee/publication/285406363_VAT_Reform_in_Banglad esh_Perspectives_on_Tax_Morale/links/565ded7f08ae1ef9298391aa.pdf

Sarker, T. K. (2003). Improving Tax Compliance in Developing Countries via Self-Assessment Systems-What Could Bangladesh Learn from Japan. Asia-Pacific Tax Bulletin, 9(6), 3-34. Retrieved from http://citeseerx.ist.psu.edu/viewdoc/download?doi=10.1.1.581.8719\&rep=rep1\&type=pdf

Ser, P. C. (2013). Determinants of Tax Non-Compliance in Malaysia (Doctoral dissertation, UTAR).

Stevens, J. (2002). Applied Multivariate Statistics for the Social Sciences. Mahwah, NJ: Erlbaum.

Torgler, B. (2003). Tax Morale, Rule-Governed Behaviour and Trust. Constitutional Political Economy, 14(2), 119-140. https://doi.org/10.1023/A:1023643622283

Torgler, B. (2004). Tax Morale in Asian Countries. Journal of Asian Economics, 15(2), 237-266. https://doi.org/10.1016/j.asieco.2004.02.001

Wahlund, R. (1992). Tax Changes and Economic Behavior: The Case of Tax Evasion. Journal of Economic Psychology, 13(4), 657-677. https://doi.org/10.1016/0167-4870(92)90017-2

Wenzel, M. (2004). An Analysis of Norm Processes in Tax Compliance. Journal of Economic Psychology, 25(2), 213-228. https://doi.org/10.1016/S0167-4870(02)00168-X

Witte, A. D., \& Woodbury, D. F. (1985). The Effect of Tax Laws and Tax Administration on Tax Compliance: The Case of the US Individual Income Tax. National Tax Journal, 38(1), 1-13.

Young, J. C. (1994). Factors Associated with Noncompliance: Evidence from the Michigan Tax Amnesty Program. The Journal of the American Taxation Association, 16(2), 82-105.

\section{AUTHORS' SHORT BIOGRAPHIES}

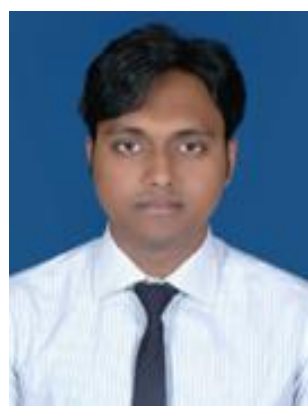

Ashir-In-Tishar is a Research Officer at Unnayan Shamannay, Dhaka, Bangladesh. He started his career as a Research Assistant at the Bangladesh Institute of Social Research Trust. He has been conducting research on economic policy, political economics, development issues, poverty and international trade. He has a published article on nominal exchange rate of Bangladesh. His research interests are macroeconomics, public sector economics, monetary and financial economics, political economics and development economics.

Ashir-In-Tishar completed his MSS (with thesis) in Economics from Shahjalal University of Science \& Technology, Sylhet (with distinction).

E-mail: ashirint013@gmail.com 


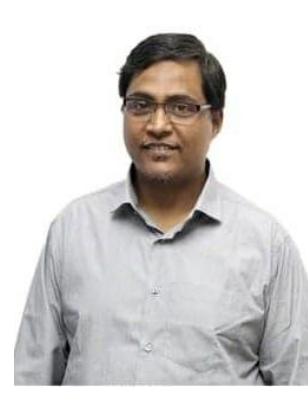

Syed Hasanuzzaman is a Professor of the Department of Economics at Shahjalal University of Science \& Technology, Sylhet, Bangladesh. He started his career as a Lecturer at the same department. Mr. Hasanuzzaman has research interest in energy economics, entrepreneurship, micro aspects of development economics. He has around 10 articles in different international journals.

Syed Hasanuzzaman completed his MA in Economics from Carleton University, Canada.

E-mail: shzaman111@gmail.com 